\title{
Carbon Sequestration Potential of Privately Managed Swietenia macrophylla Plantations in the Wet and Intermediate Zones of Sri Lanka
}

\author{
Perera L.S.A.* and Ranasinghe D.M.S.H.K.
}

\author{
Department of Forestry and Environmental Science, Faculty of Applied Scienses, \\ University of Sri Jayewardenepura, Nugegoda, Sri Lanka \\ * sanomi.perera20@gmail.com
}

\begin{abstract}
Global warming is the most widespread problem of the new millennium. Carbon dioxide $\left(\mathrm{CO}_{2}\right)$ is the most important greenhouse gas released as a result of human activities. As a consequence, global average temperature is projected to increase by 1.4 to $5.80 \mathrm{C}$ over the period of 1990 to 2100 . Forest tree plantations play an important role in reducing this atmospheric carbon dioxide through carbon sequestration through photosynthesis and storing the carbon within their biomass. The objective of the present study was to investigate the carbon sequestration potential of different aged Swietenia macrophylla (Mahogany) established by a private tree planting company (Touchwood plantations in the Wet and Intermediate zones of Sri Lanka).

The ages ranged from 6 to 14 years and the total extent was 936.48 ha and the total number of trees was 443,516. The available literature on the dbh and height of the trees in all the plantations were taken. In each selected age class representative trees were taken for detailed sampling for aboveground and belowground biomass measurements as well as aboveground component biomass. Using the wet:dry ratios from destructive sampling the dry weights of all the tree components were estimated. Using the equation $\mathrm{W}_{\mathrm{C}}=\mathrm{W} * 0.5\left(\mathrm{~W}_{\mathrm{C}}=\right.$ weight of carbon, $\mathrm{W}=$ weight of biomass) the carbon content lodged in the components of the biomass was calculated. Using the equation $\mathrm{WCO}_{2}=\mathrm{W}_{\mathrm{C}} * 3.67$ the carbon dioxide content in biomass was calculated. Total litter fall was assessed by litter traps and the rate of litter decomposition was estimated.
\end{abstract}

According to the results the total carbon sequestration potential of the 12 years aged plantations was $187.89 \mathrm{mt} / \mathrm{ha}$ followed by 11 years aged plantations $(146.83 \mathrm{mt} / \mathrm{ha}), 10$ years aged plantations $(90.52 \mathrm{mt} / \mathrm{ha}), 9$ years aged plantations $(42.22 \mathrm{mt} / \mathrm{ha}), 8$ years aged plantations $(38.50 \mathrm{mt} / \mathrm{ha}), 7$ years aged plantations $(17.11 \mathrm{mt} / \mathrm{ha}), 6$ years aged plantations recorded the lowest $(9.05 \mathrm{mt} / \mathrm{ha})$. When considering the tree component contribution towards the total carbon stock the highest contribution comes from the stem followed by the root, branches and the lowest from the leaves. The total ecosystem carbon sequestration including the contribution from litter fall and release to the atmosphere are also included in the presentation.

Keywords: Carbon sequestration, Swietenia macrophylla 